Article

\title{
Hindrances to Effective Implementation of the Habitats Directive in Italy: Regional Differences in Designating Special Areas of Conservation
}

\author{
Sabrina Lai $\mathbb{D}$ \\ Dipartimento di Ingegneria Civile, Ambientale e Architettura, University of Cagliari, 09123 Cagliari CA, Italy; \\ sabrinalai@unica.it
}

Received: 18 February 2020; Accepted: 16 March 2020; Published: 17 March 2020

check for updates

\begin{abstract}
Natura 2000" is a coordinated network of protected areas that stretches across the European Union in compliance with two directives (the so-called "Habitats Directive" and the "Birds Directive") that underpin the Union's policies on biodiversity conservation. This study is aimed at assessing the implementation of the network by qualitatively analyzing how Special Areas of Conservation are being designated. Such designation process, which is being implemented, although with great delay, in a number of member states, entails the establishment of site-specific conservation measures that may be included within appropriate management plans or other development plans. A systematic documental analysis of official acts establishing Special Areas of Conservation and approving conservation measures and management plans was performed by taking Italy as a case study. The analysis focuses on four key topics, as follows: use of conservation measures and appropriate management plans; multi-level governance of the Natura 2000 sites, in terms of involved institutions and tiers of government; stakeholders' inclusion in the designation process; and the relationship between conservation measures and the wider spatial planning system. The results show significant differences regarding the implementation of the Natura 2000 network and highlight potential general hindrances to completing the designation process in the European Union.
\end{abstract}

Keywords: Natura 2000 network; natural protected areas; environmental planning; multi-level governance

\section{Introduction}

Biodiversity protection in the European Union (EU) is grounded on two cornerstones: First, the EU Biodiversity Strategy, initiated in 1998 [1] and revised in 2011 [2]. Second, a legal framework whose main pillars are Council Directive 92/43/EEC of 21 May 1992 on the conservation of natural habitats and of wild fauna (the so-called "Habitats Directive"), Directive 2009/147/EC of the European Parliament and of the Council of 30 November 2009 on the conservation of wild birds, and the codified version of Council Directive 79/409/EEC of 2 April 1979 (the so-called "Birds Directive"). The legal framework establishes a strict protection regime for wildlife and their habitats; in addition, it creates an international, yet coordinated, network of protected areas aimed at maintaining or restoring biodiversity at a favorable conservation status both inland and at sea. Named "Natura 2000", this network comprises Sites of Community Importance (SCIs), Special Areas of Conservation (SACs), and Special Protection Areas (SPAs), and it spreads across more than $18 \%$ of the EU territory and over 530,000 square kilometers of sea waters [3].

If we were to follow Ostrom's view [4] (p. 1), Natura 2000 could be regarded as the EU tool designed to "govern natural resources used by many individuals in common" where an institution sets limits on the use of natural resources so as to ensure their long term maintenance and, by doing so, 
even their benefits (be they economic or non-economic) for people. It is considered in the literature as a champion example of an international network of protected areas $[5,6]$ and as an outstanding implementation of biodiversity-related spatial policies [7], to the extent that Campagnaro et al. [8] state that it has made "unprecedented advances in implementing effective, evidence-based, internationally collaborative conservation policies and practices at continental scales".

But how can the effectiveness of biodiversity conservation policies be evaluated? Rauschmayer et al. [9] suggest that this can be done by assessing either their outcomes or their implementation processes.

As for outcome assessments, several studies have evaluated improvements in the conservation statuses of species and habitats since the establishment of the Natura 2000 network so as to assess its contribution to biodiversity protection. Some studies consider a specific country, or a set of countries: Among these, for instance, Maiorano et al. [10], McKenna et al. [11], and Trochet and Schmeller [12]. Other studies focus on a certain species, or a certain taxonomic rank (for instance, [13-15]) to analyze trends in their conservation statuses and understand whether such trends are linked to the establishment of the protection regime in force in Natura 2000 sites.

As for process evaluation, a number of interdisciplinary studies analyzed the establishment of the Natura 2000 network [16,17], its management [18], participation processes [19-22], and conflicts [23,24].

Under article 4.4 of the Habitats Directive, within six years from their establishment SCIs (identified by member states on scientific grounds only) are bound to be designated as SACs. The SAC designation process must be preceded by the establishment of site-specific "necessary conservation measures involving, if need be, appropriate management plans specifically designed for the site or integrated into other development plans" (article 6.1); such measures need to take "account of economic, social, and cultural requirements and regional and local characteristics" (article 2.3). Thus, as noted by Bouwma et al. [25], member states are provided with some degree of freedom as regards the management of the network, as they can choose either to "simply" identify conservation measures that should be implemented or to integrate them within planning tools (either existent ones or ones prepared ad-hoc-in the latter case, they are termed "management plans"). The voluntary character envisioned in the directive notwithstanding, ad-hoc plan-making processes (i.e., the definition of management plans containing the required conservation measures) are regarded in several studies as the way forward to mitigate conflicts $[26,27]$ and as the optimal tool to include stakeholders' participation $[16,28-30]$; management plans have therefore been found to be preferred over stand-alone conservation measures in a number of member states and have been promoted by the EU [25]. Moreover, inclusive plan-making processes are regarded in the literature as a proper counterbalance to the top-down process whereby Natura 2000 sites were identified and designated [31].

However, the form that management plans take is heavily shaped by the way spatial planning is understood and implemented in the various member states as regards goal setting and regulation [25]; in addition, the practical implementation of management plans for biodiversity conservation can conflict with planning tools already in place at the regional and local levels, prominently land-use plans and territorial plans for economic development [32]. Hence, their effectiveness depends on the extent to which spatial planning integrates Natura 2000 sites [33], as land use regimes and policies should often be adjusted [34] to meet conservation goals, and therefore also on the planning system in force and the extent to which it allows for such integration.

Moreover, huge delays have generally been observed in setting conservation objectives and putting management plans in place $[35,36]$. This calls for more research to understand the reasons behind such low compliance with the directive, possibly signaling that competent authorities did not agree on what needs to be achieved on the sites [35], which, in turn, is highly likely to hinder progresses towards the broad objectives of biodiversity conservation.

So far, only a few studies have investigated the establishment of conservation measures (also including plan-making processes); one reason behind the low interest of the academic literature might possibly be attributed to the low involvement of the academic world in the establishment of conservation measures (eventually included within management plans). Among these studies, 
Gil et al. [37], who propose a step-by-step methodology to prepare a Natura 2000 site management plan, tested in the Azores region in Portugal; Kovacs et al. [38], who analyze the way in which management plans were drafted for 25 Hungarian sites; and Cortina and Boggia [39], who define a methodology aimed at ascertaining whether, within a certain Natura 2000 site, the establishment of appropriate conservation measures is sufficient to pursue the directive's goals, or if a management plan is necessary.

Building upon current literature, this study is aimed at addressing the research gap identified above by analyzing the ongoing process through which SACs are being designated by means of an analysis of official documents that establish Natura 2000 conservation measures (CMs) or approve management plans (MPs).

Italy is selected as a case study because the SAC designation process has almost been completed, although with great delay with respect to the six-year deadline mandated by the Habitats Directive; such delay in October 2015 led to a formal notice (infringement procedure no. 2015-2163) from the European Commission, and, in January 2019, to an additional formal notice because of the still unachieved compliance. Similar formal notices, concerning issues in SAC designation, were also issued to other member states, including Portugal (no. 2015-2002), Spain (no. 2015-2003), Ireland (no. 2015-2006), Greece (no. 2015-2260), Germany (no. 2015-2262), Bulgaria (no. 2018-2352), and Slovakia (no. 2019-2141); none of these infringement procedures has been closed so far [40], which signals a general difficulty in fully implementing the Natura 2000 network, and the Italian case can shed some light on such issues.

The following section introduces the case study and provides the reader with both quantitative data on the Italian Natura 2000 network and a brief historic and normative description concerning the roles entrusted to the various institutions involved in the sites' identification as well as in the establishment and management of the network. In the third section, the qualitative methodology is presented, while results of the analysis are provided with reference to each Italian region or autonomous province in the fourth section. Next, the results are discussed in the fifth section, focusing on four topics as follows: the integration of CMs and MPs in ordinary spatial and territorial plans; differences, across regions, as to institutions and tiers of government involved in the management and planning of Natura 2000 sites; stakeholders' inclusion in the identification of CMs and preparation of MPs; and the nature and role of CMs and MPs in the Italian multilevel and hierarchical planning framework. Final conclusions are provided in the sixth section.

\section{The Natura 2000 Network in Italy}

The Natura 2000 network in Italy stretches over $64,124 \mathrm{~km}^{2}$, of which land area amounts to $57,265 \mathrm{~km}^{2}$, corresponding to approximately $19 \%$ of the national territory, and marine area amounts to $6859 \mathrm{~km}^{2}$ [3]. To date, 2613 sites have been designated in Italy, of which 2335 have been identified as SCIs under the Habitats Directive. For 2307 SCIs, the six-year deadline for their designation as SACs has expired; as of December 31 $1^{\text {st }} 2019,2261$ sites have been designated as SACs (data retrieved from the institutional website of the Italian Ministry of the Environment and Land and Sea Protection http://www.minambiente.it/pagina/zsc-designate). Out of these 2261 SACs, only 403 had been designated before the infringement procedure was issued, thus well after the deadline had expired (it is therefore highly likely that such notice greatly accelerated the designation process), while the process is yet to be completed for the remaining SCIs.

Natura 2000 sites in Italy were initially identified within the "Bioitaly" project (1994-1998) by the Ministry for the Environment, supported by national scientific societies [41], and with the involvement of lower tiers of government [42], i.e., regions and the autonomous provinces of Trento and Bolzano, in turn supported by local universities and research centers [43]. On purely scientific bases, in compliance with the directive, around 2800 sites [44] were thus identified, which led to conflicts and resistance, both from stakeholders and municipalities [45], who complained about being left out of the process. A few years later, in April 2000, the Minister of the Environment issued a decree that also approved, besides the first list of SPAs, a preliminary list of proposed SCIs to be forwarded to 
the European Commission for designation (due to the encountered opposition, the two lists did not include all of the 2800 sites that had preliminarily been identified), which had to be finalized through a Commission Decision.

Following the sites' designation, each member state had to define the necessary site-specific CMs within six years of the lists being adopted (Commission Decisions approving lists of SCIs for the various biogeographic regions can be accessed from the EU Commission's website: https: //ec.europa.eu/environment/nature/natura2000/biogeog_regions/index_en.htm); hence, as regards Italy, in 2010 for sites belonging to the Alpine and Continental biogeographic regions and in 2012 for the Mediterranean biogeographic region.

In Italy, the State (which is responsible for implementing the Habitats Directive) has delegated the identification of CMs and the preparation of MPs, as well as their approval, to its 19 regions and two autonomous provinces (as per the decree of the President of the Republic, no. 357/1997), while retaining, at the state level, the designation of SACs through a decree of the Ministry of the Environment and Land and Sea Protection.

Roles and responsibilities concerning the implementation of the Habitats Directive in Italy are therefore multilayered: First, the State, which proposes the lists of SCIs to the European Commission and designates the SACs; second, the European Commission, which adopts the lists of SCIs; third, the regions and autonomous provinces, which define and approve CMs and MPs as a prerequisite to SAC designation and are responsible for the management of the sites.

Figure 1 shows how the site designation process envisioned in the Habitats Directive works, from the preliminary identification of SCIs to the designation of SACs; moreover, it sums up the main aspects concerning the processes, approaches, and stakeholders' engagement. As portrayed in the image, the designation process is characterized by a rigid, hierarchical separation of the involved institutional tiers of government, and by technocratic approaches grounded only upon scientific data, in the absence of any participation of local communities and stakeholders who might possibly be involved in the sites' management. In other words, the first part of the process (SCI identification and designation), driven by scientific data and led by institutions, takes a top-down approach that leaves out local communities' and economic stakeholders' interests; such exclusion may—or may not—be compensated in the final part (SAC establishment and management), depending on how each member state designs the process.

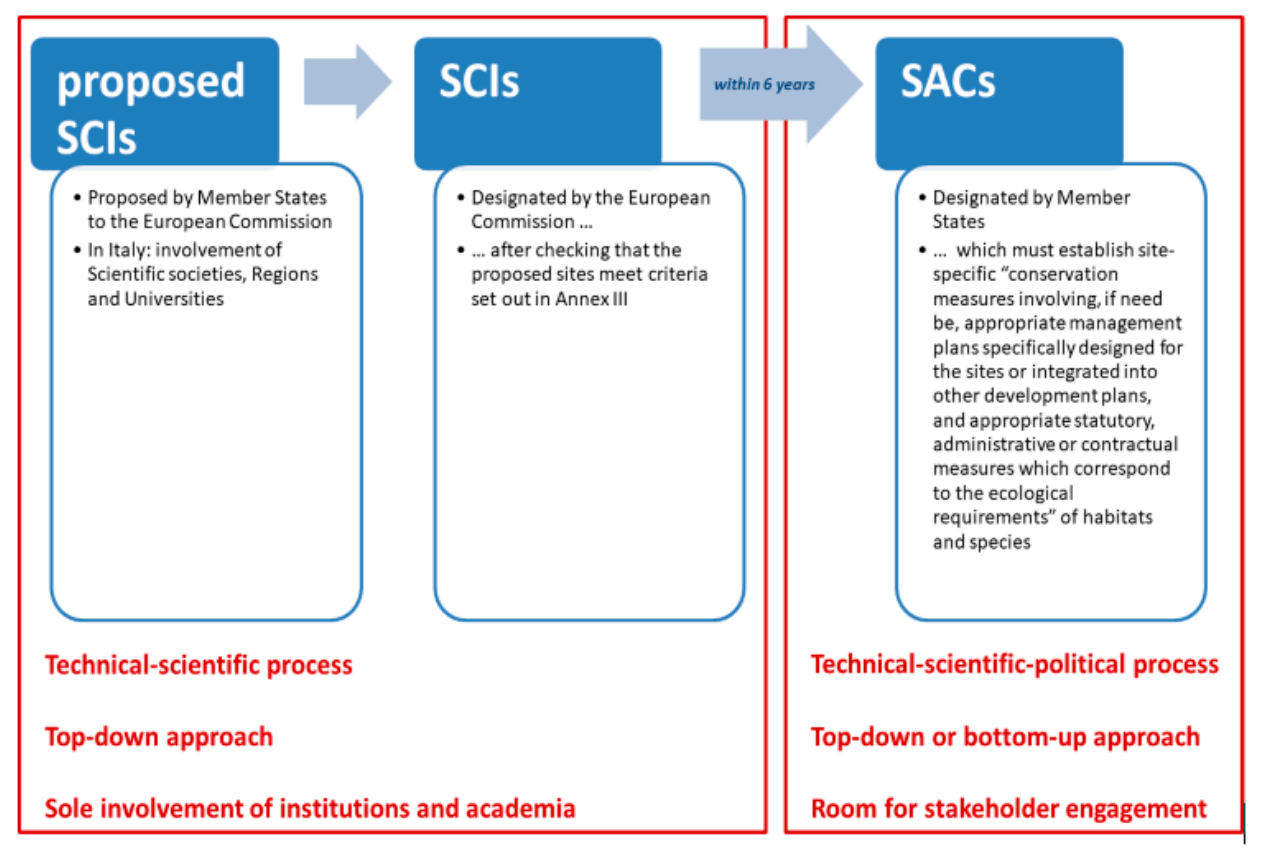

Figure 1. From preliminary identification of proposed Sites of Community Importance (SCIs) to designation of Special Areas of Conservation (SACs): roles, approaches, and stakeholders' involvement. 
Figure 2 highlights the final part of the designation process shown in Figure 1 (hence, the transition from SCIs to SACs) and identifies the institutional tiers of government involved in the process in Italy, therefore highlighting the roles and responsibilities of the European Commissions, of the State, and of the regions and autonomous provinces. As previously mentioned, the Italian State has delegated the obligation to identify and approve CMs (sometimes included within MPs) to regions and autonomous provinces through the decree of the President of the Republic, no. 357/1997. Once CMs (or, optionally, an MP which includes them) are approved for a Natura 2000 site, the Ministry of the Environment and Land and Sea Protection checks them against the Habitats Directive's requirements, and, if the measures are deemed to be adequate, the site is established as a SAC through a ministerial decree. Finally, the State must provide information and official acts concerning SAC establishment to the European Commission, and it is also responsible for the six-year reporting on habitats' and species' conservation status, and therefore on the effectiveness of its Natura 2000 network in pursuing the ultimate goal of contributing to global biodiversity protection.

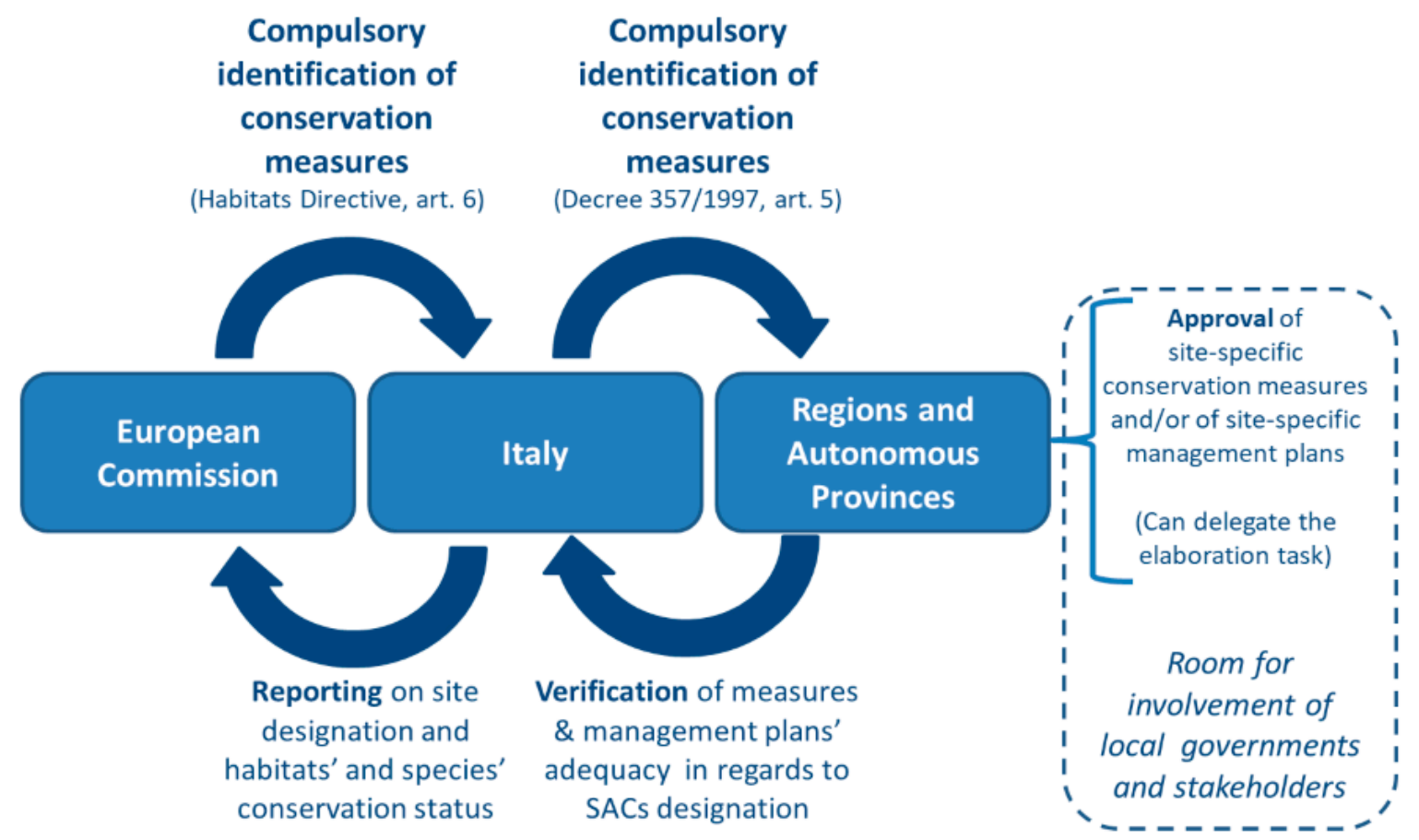

Figure 2. SAC designation in Italy: The State's obligations stemming from the Habitats Directive are transferred to the regions and autonomous provinces (upper arrows), which identify conservation measures and prepare management plans, while the State checks the measures, designate the SACs, and is accountable to the European commission (lower arrows).

\section{Materials and Methods}

For this research, a documentary case-study analysis was carried out. As stated in the Introduction, the SAC designation process in Italy has almost been completed, although with great delay with respect to the timeframe envisioned within the Habitats Directive. Thus, Italy is an "intrinsically interesting" [46] case study to analyze processes leading to SAC designation characterized by a high level of delay, because this case study can shed some light on institutional hindrances in designating SACs.

The documentary analysis was performed on official documents retrieved from the website of the Italian Ministry for the Environment and Land and Sea Protection [47] (monitored from July 2018 until December 2019), with a view to evaluating governance and inclusion mechanisms implemented in the management of the Natura 2000 Network in Italy. Since most of the official acts (i.e., the decrees of the State Minister for the Environment or deliberations of the regional executives) were available only as scanned documents, text mining techniques could not be applied. All of the official state and 
regional acts concerning SAC establishment were thoroughly read and analyzed, and their numbers are as follows:

- At the state level: approximately 70 ministerial decrees concerning SACs' designations;

- At the regional/local level: deliberations of local regional governments, or deliberations of natural parks' councils, approving site-specific CMs or MPs; a total of approximately 440 acts.

A preliminary "searching-out of underlying themes" of interest [48] (p. 557) was performed to double-check which information on issues emerging from the literature review, as presented in Section 1, could be retrieved. This search led to selecting the following four topics:

- $\quad$ Type of tool that was chosen, i.e., CMs or MPs, or both;

- Governance of the processes, i.e., institutions in charge of the definition of CMs and MPs;

- Level of inclusion within the processes, i.e., institutional and stakeholders' involvement in shaping CMs and MPs;

- Implications on spatial planning entailed by CMs and MPs.

Subsequently, once the topics of interest had been identified, all of the documents were scrutinized and fragments concerning the four topics were looked for, code, and noted at the site level.

According to Bryman [48] (p. 550), state-produced documents readily fulfill two of the four criteria that, according to Scott [49], should be looked for in social science research (i.e., authenticity and meaning), while issues of representativeness and credibility can sometimes be raised. Issue of representativeness (i.e., evidence that the documents analyzed are typical of their kind) can be excluded since, in this study, all of the available documents whereby SACs have been established in Italy were read and analyzed, without limiting the analysis to a sample. As for credibility, the official documents here analyzed do not provide any straight interpretations, opinions, or judgments, because they merely establish that a specific type of already-designated Natura 2000 site (namely, an SCI) is converted into another type (namely, an SAC) and enlist CMs to be enforced; however, the very fact that they approve a vision for the concerned sites, objectives to be pursued, and actions to be prioritized does provide an underlying official narrative about the significance or value of the sites.

\section{Results}

Results of the analysis are summarized in Table 1, which, for each region or autonomous province, provides: Progress towards designation completion (as: SCIs not yet designated as SACS, Column 2, and total number of SACs designated as of December 2019, Column 3); number of SACs designated based upon MPs or CMs (Columns 4 and 5); type of institution responsible for MP or CM preparation (Columns 6; note that their approval always lies with the region, or with the autonomous provinces of Trento and Bolzano in the case of Trentino-South Tirol); type of participation processes implemented, if any (Column 7); and whether any planning implication is entailed by MPs or CMs (Column 8).

Columns 2 and 3 in Table 1 show that the SAC designation process in Italy, although still incomplete, is nearing its end: If one takes into account that 20 out of the 74 SCIs still to be designated as SACs were established in 2017-2018 (which means that the six-year deadline has not passed yet for these sites), then conservation measures are in force in $97.67 \%$ of the sites, and the process has been completed in seven regions (Apulia, Basilicata, Campania, Liguria, Molise, Umbria, and Veneto). Figure 3 shows the geographical distribution of SCIs and SACs in Italy as of December 31, 2019, while Figure 4 shows how the process has progressed in time, by differentiating SACs on the basis of their designation year. 
Table 1. The SAC designation process in Italy: Progress towards completion (number of SCIs still to be designated as SACs and number of SACs designated, Columns 2 and 3, respectively), number of SACs designated based on MPs and CMs (Columns 4 and 5), responsible institution for CM identification or MP preparation (Column 6), participatory processes carried out (Column 7), whether any planning relevance can be elicited from the official acts approving CMs and MPs (Column 8). All information is provided at the regional level. Source: Author's elaboration on documents retrieved from ftp://ftp.minambiente.it/PNM/Natura2000/Materiale\% 20Designazione\%20ZSC - last access on December 31, 2019).

\begin{tabular}{|c|c|c|c|c|c|c|c|}
\hline $\begin{array}{l}\text { 1) Regions and } \\
\text { Autonomous } \\
\text { Provinces }\end{array}$ & $\begin{array}{l}\text { 2) SCIs Not } \\
\text { Yet SACs }\end{array}$ & 3) No. SACs & $\begin{array}{l}\text { 4) No. SACs } \\
\text { with MPs }\end{array}$ & $\begin{array}{l}\text { 5) No. SACs } \\
\text { with CMs }\end{array}$ & $\begin{array}{l}\text { 6) Responsible Institution for } \\
\text { CM/MP Preparation }\end{array}$ & $\begin{array}{l}\text { 7) Participatory } \\
\text { Processes }(*)\end{array}$ & $\begin{array}{l}\text { 8) Planning } \\
\text { Relevance }\end{array}$ \\
\hline Abruzzo & 3 & 193 & --- & 193 & CMs: Region MPs: Local authorities (MPs) & 2 & \\
\hline Aosta Valley & 1 & 76 & 32 & 44 & $\begin{array}{l}\text { Municipalities, Provinces, and Protected } \\
\text { areas }\end{array}$ & $\begin{array}{c}2 \text { (CMs and MPs) } \\
4 \text { (MPs) }\end{array}$ & \\
\hline Apulia & --- & 85 & 60 & 25 & Region, a Mountain community & $\begin{array}{l}2 \text { (MPs by mountain } \\
\text { communities), } \\
2+3 \text { (MPs by the region) }\end{array}$ & X (MPs only) \\
\hline Basilicata & 10 & 122 & 4 & 118 & Region (CMs), Protected areas (MPs) & $\begin{array}{l}2,4 \text { (only in a } \\
\text { few instances) }\end{array}$ & \\
\hline Calabria & 14 & 79 & 65 & 14 & $\begin{array}{l}\text { CMs: RegionMPs: Protected areas, } \\
\text { Provinces, Municipalities }\end{array}$ & 2, 4 (MPs); 1 (CMs) & $x$ \\
\hline Campania & 16 & 207 & 203 & 4 & $\begin{array}{l}\text { Protected areas, Provinces, Regional } \\
\text { forestry agency, University, } \\
\text { non-governmental organizations }\end{array}$ & --- & \\
\hline Emilia-Romagna & 4 & 40 & --- & 40 & Province & 2 & $x$ \\
\hline $\begin{array}{l}\text { Friuli-Venezia } \\
\text { Giulia }\end{array}$ & 1 & 135 & --- & 135 & Province, Protected areas & 2,4 & \\
\hline Lazio & 1 & 134 & --- & 134 & $\begin{array}{l}\text { RegionFor one marine site overlapping one } \\
\text { Marine Protected Area, the Ministry for } \\
\text { the Environment }\end{array}$ & 1 & \\
\hline Liguria & --- & 97 & --- & 97 & Region & 2,3 & $\begin{array}{l}\mathrm{X} \text { (only as } \\
\text { regards } \\
\text { consultation) }\end{array}$ \\
\hline
\end{tabular}


Table 1. Cont.

\begin{tabular}{|c|c|c|c|c|c|c|c|}
\hline $\begin{array}{l}\text { 1) Regions and } \\
\text { Autonomous } \\
\text { Provinces }\end{array}$ & $\begin{array}{l}\text { 2) SCIs Not } \\
\text { Yet SACs }\end{array}$ & 3) No. SACs & $\begin{array}{l}\text { 4) No. SACs } \\
\text { with MPs }\end{array}$ & $\begin{array}{l}\text { 5) No. SACs } \\
\text { with CMs }\end{array}$ & $\begin{array}{l}\text { 6) Responsible Institution for } \\
\text { CM/MP Preparation }\end{array}$ & $\begin{array}{l}\text { 7) Participatory } \\
\text { Processes (*) }\end{array}$ & $\begin{array}{l}\text { 8) Planning } \\
\text { Relevance }\end{array}$ \\
\hline Lombardy & --- & 104 & --- & 104 & Region & 2 & \\
\hline Marche & 3 & 193 & --- & 193 & CMs: RegionMPs: Local authorities (MPs) & 2 & \\
\hline Molise & 1 & 76 & 32 & 44 & $\begin{array}{c}\text { Municipalities, Provinces, and } \\
\text { Protected areas }\end{array}$ & $\begin{array}{c}2 \text { (CMs and MPs) } \\
4 \text { (MPs) }\end{array}$ & \\
\hline Piedmont & --- & 85 & 60 & 25 & Region, a Mountain community & $\begin{array}{l}2 \text { (MPs by mountain } \\
\text { communities), } 2+3 \text { (MPs } \\
\text { by the region) }\end{array}$ & X (MPs only) \\
\hline Sardinia & 10 & 122 & 4 & 118 & Region (CMs), Protected areas (MPs) & $\begin{array}{l}2,4 \text { (only in a few } \\
\text { instances) }\end{array}$ & \\
\hline Sicily & 14 & 79 & 65 & 14 & $\begin{array}{l}\text { CMs: RegionMPs: Protected areas, } \\
\text { Provinces, Municipalities }\end{array}$ & 2, 4 (MPs); 1 (CMs) & $x$ \\
\hline $\begin{array}{l}\text { Trentino-S.T. } \\
\text { Bolzano province }\end{array}$ & 16 & 207 & 203 & 4 & $\begin{array}{l}\text { Protected areas, Provinces, Regional } \\
\text { forestry agency, University, } \\
\text { non-governmental organizations }\end{array}$ & --- & \\
\hline $\begin{array}{l}\text { Trentino-S.T. } \\
\text { Trento province }\end{array}$ & 4 & 40 & --- & 40 & Province & 2 & $x$ \\
\hline Tuscany & 1 & 135 & --- & 135 & Province, Protected areas & 2,4 & \\
\hline Umbria & 1 & 134 & --- & 134 & $\begin{array}{c}\text { RegionFor one marine site overlapping one } \\
\text { Marine Protected Area, the Ministry for } \\
\text { the Environment }\end{array}$ & 1 & \\
\hline Veneto & --- & 97 & --- & 97 & Region & 2,3 & $\begin{array}{l}\mathrm{X} \text { (only as } \\
\text { regards } \\
\text { consultation) }\end{array}$ \\
\hline TOTAL & 74 & 2,261 & 460 & 1,801 & & & \\
\hline
\end{tabular}




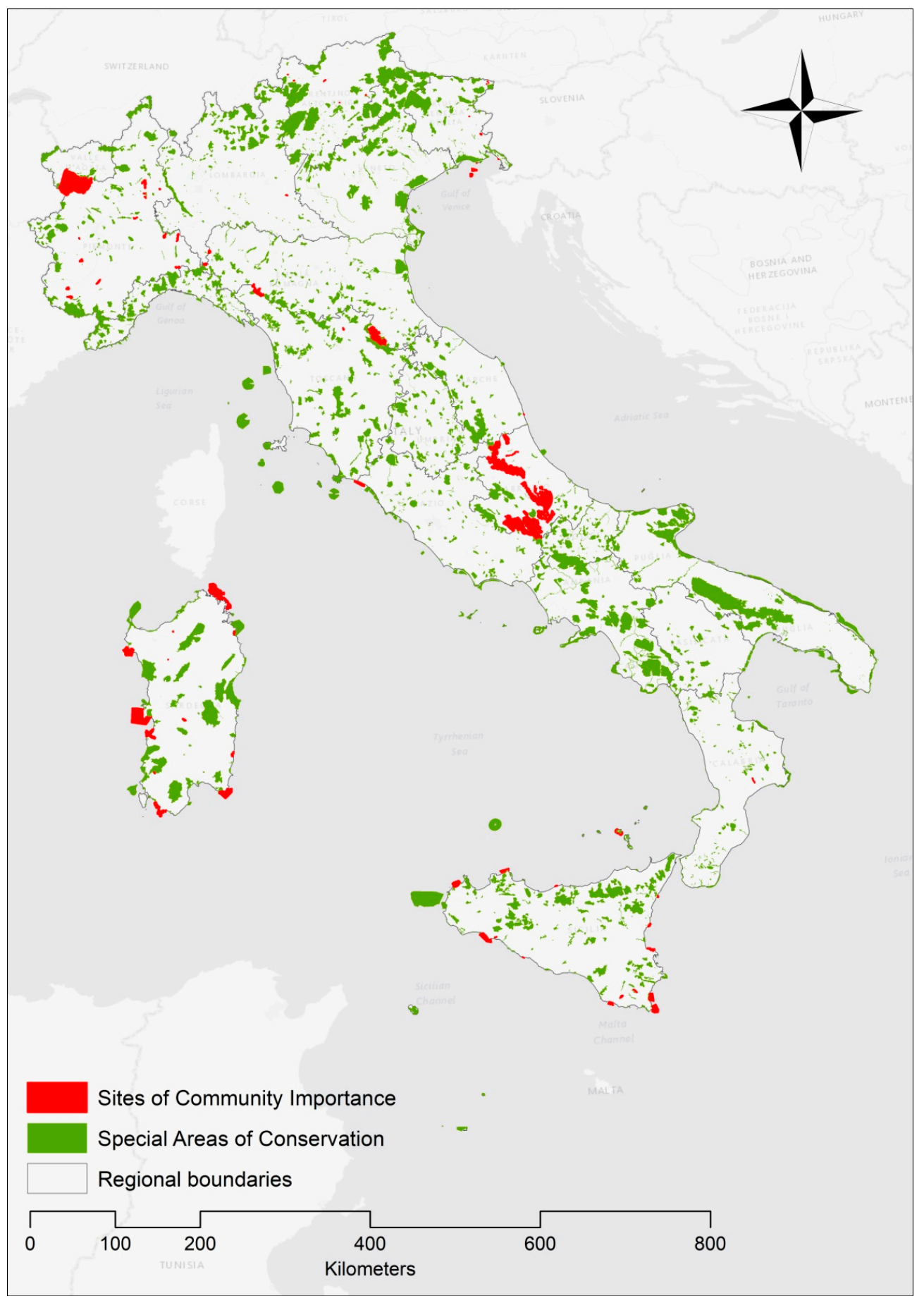

Figure 3. Sites of Community Importance and Special Areas of Conservation in Italy: designation process as of December 2019 (source: Author's own elaboration; Natura 2000 sites' boundaries retrieved from ftp://ftp.minambiente.it/PNM/Natura2000/TrasmissioneCE_dicembre2017/, last access on December 31, 2019). 


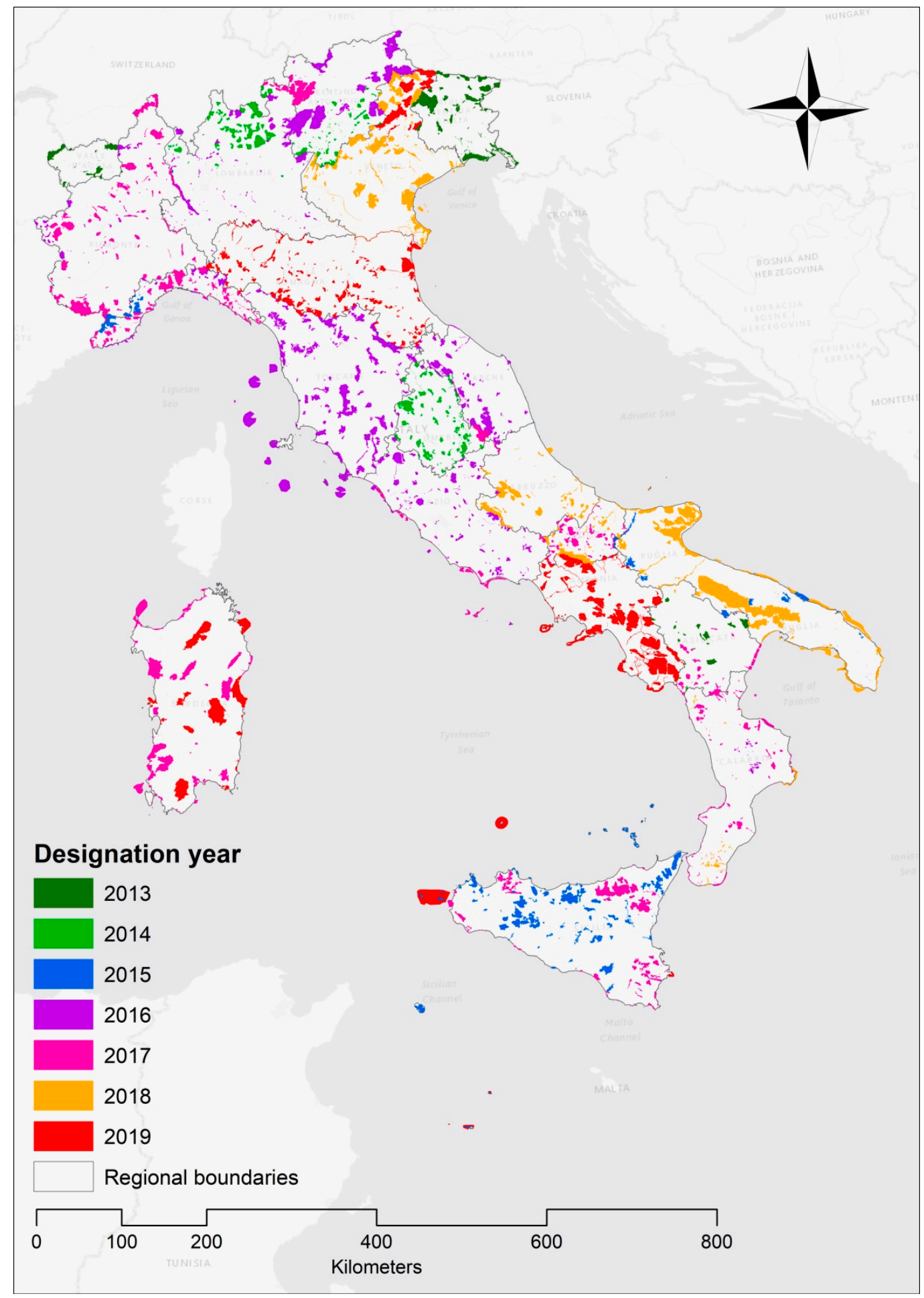

Figure 4. Special Areas of Conservation in Italy by designation year (source: Author's own elaboration; Natura 2000 sites' boundaries retrieved from ftp://ftp.minambiente.it/PNM/Natura2000/ TrasmissioneCE_dicembre2017/, last access on December 31, 2019).

Column 4 and 5 in Table 1 provide quantitative information on the number of SACs that were designated based on MPs and CMs, respectively. Eleven regions have made use of both CMs and MPs; eight regions and the two autonomous provinces of Bolzano and Trento have approved only $\mathrm{CMs}$, while in no region were all of the SACs designated based on MPs. A graphical representation is provided in Figure 5, where SACs are differentiated based on whether CMs or MPs were used for 
their designation; this figure also highlights that, for four marine sites overlapping as many Marine Protected Areas (MPAs) (one in Tuscany and three in Lazio), SACs where designated on the basis of their MPA regulatory tools only, defined at the state level (by the Ministry of the Environment and Land and Sea Protection), which are regarded as the sites' CMs.

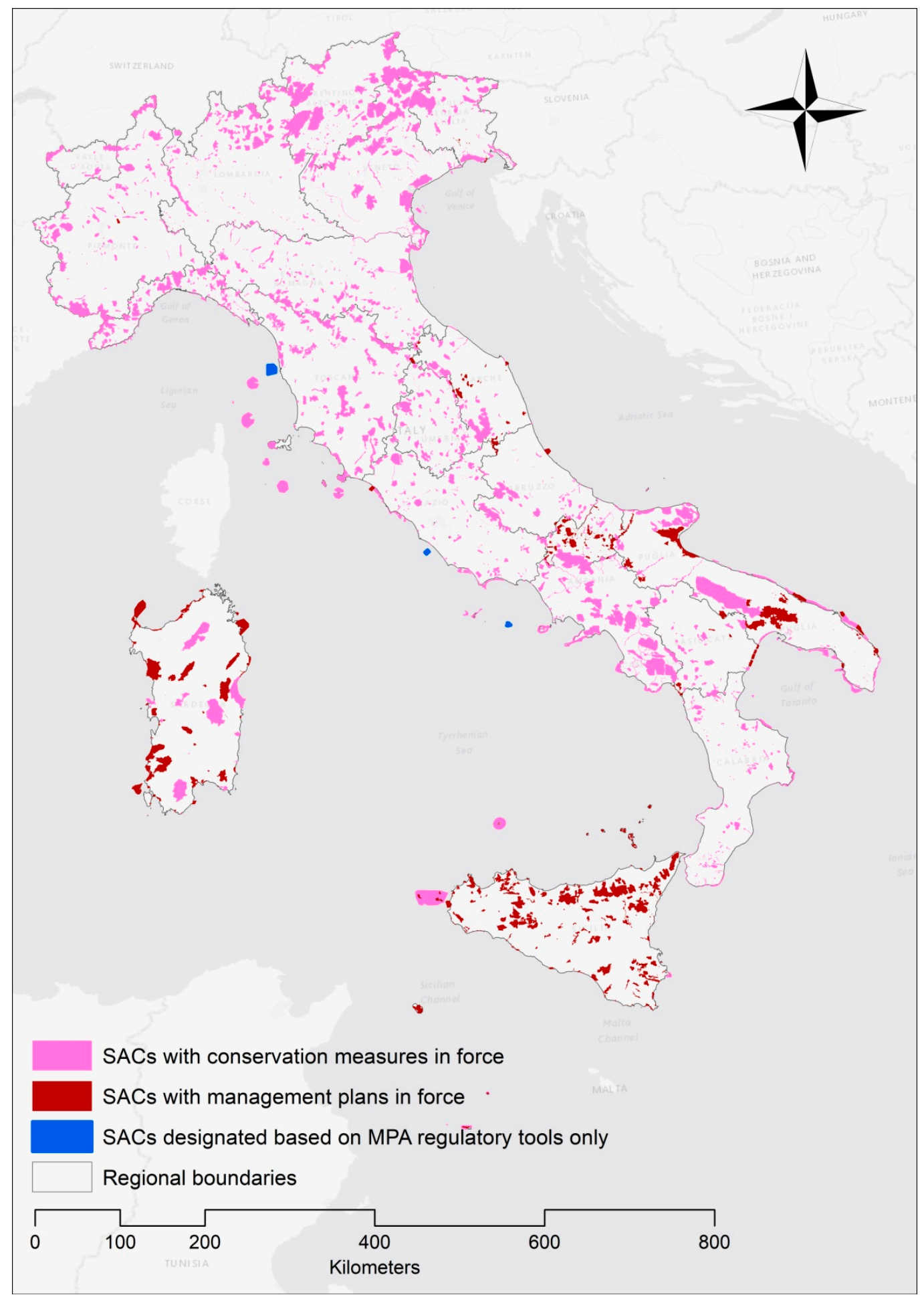

Figure 5. Special Areas of Conservation in Italy for which the official designation acts refer to conservation measures, management plans or (exclusively) MPA regulatory tools (source: Author's own elaboration; Natura 2000 sites' boundaries retrieved from ftp://ftp.minambiente.it/PNM/Natura2000/ TrasmissioneCE_dicembre2017/, last access on December 31, 2019). 
Column 6 provides information on which institution prepared CMs and MPs: While regions, or in the cases of Trentino Alto Adige and the autonomous provinces of Trento and Bolzano, retain the power to approve CMs and MP, they can delegate their preparation to other institutions. Each of the regions has therefore decided whether to carry out this task itself (some, such as Basilicata, have established internal offices or working groups while others, such as Veneto, have involved a local university, and others, like Molise or Apulia, have contracted external consultants) or whether to delegate lower tiers of government, such as provinces, municipalities, or mountain communities (which, in Italy, were statutory associations of mountain and hill municipalities). In the case of a Natura 2000 site overlapping a natural protected area such as a natural park or a nature reserve, some regions (for instance, Calabria, Lazio, Marche, Piedmont, and Sardinia), as well as the autonomous province of Trento, have delegated the task to the institution in charge of the area. Finally, a small number of other organizations appear to have been delegated, but this is a very uncommon choice, only made by two regions (Liguria: the Regional Environmental Agency; Sicily: the Regional forestry agency, a University, and some non-governmental organizations).

Column 7 in Table 1 summarizes information on whether, and how, participation was implemented in the making of CMs and MPs. Participation forms significantly vary among regions, with reference not only to the categories of institutional actors and stakeholders involved, but also to types and timing of participatory processes. In two cases only (Calabria and Sicily) neither participatory nor consultative process are recorded in the official acts here examined; in some other cases (Tuscany, Aosta Valley, and, to some extent, Emilia Romagna and Sardinia) consultation appears to have been restricted to institutions only. In most regions and autonomous provinces, official acts record higher-level participatory processes that took different forms, of which the most common is the written consultation on a pre-adopted and published version of CMs and MPs, which mirrors the traditional participatory process implemented in statutory planning in Italy. Truly participative processes that involve a Natura 2000 sites' key stakeholders (such as farmers, hunters, forest managers, and tourism businesses, as well as local communities) and that are carried out during the plan-making process or CM identification, which could in theory lead to better agreed-upon CMs, are rarer. Surprisingly, even rarer are informative meetings held after MP and CM approval.

Finally, Column 8 in Table 1 signals whether any planning-related content was detected in the official acts approving CMs and MPs. Such content can take various forms: references to the regional or provincial planning laws in force (e.g., Apulia, Friuli-Venezia Giulia, Molise, and the autonomous province of Bolzano) either as regards the approval procedure or the relationship between conservation measures and land-use plans and zoning schemes; call for integration of conservation measures within local planning tools (e.g., Basilicata); references to the Strategic Environmental Assessment (e.g., Apulia, Basilicata, Marche, Sardinia), a procedure envisioned in EU Directive 2001/42/EC "on the assessment of the effects of certain plans and programs on the environment", which some regions regard as mandatory for MPs and some explicitly rule out.

\section{Discussion}

The analysis has put in evidence remarkable differences concerning the SAC designation process among Italian regions; these differences concern a number of aspects, such as: the role played by the various tiers of government involved; the way socio-cultural-economic considerations, which must be taken into account according to the Habitats Directive, are incorporated in the process; and the nature of CMs and MPs.

First, as for the type of tool, SACs have mostly been established based on CMs in all of the regions and autonomous provinces; in some regions, MPs were used as well, and they only prevailed (as far as the number of sites is concerned) in four regions. This is not surprising and is consistent with the provision of the Habitats Directive because only site-specific CMs are required, while MPs are optional. In other EU member states, an MP is mandatory for each Natura 2000 site [45,50-53], while in Italy the literal provision of the directive has been transposed into the national law regulating 
Natura 2000 network and retained within regional practices. In this regard, Ferranti et al. [52] have suggested that CMs were integrated within other development plans in most Italian regions. However, the analysis of official documents designating SACs, which enlist the measures in force in each site, has highlighted that none of the acts mention other development plans within which CMs could possibly have been integrated (such as, for instance, regional forestry plans, river basin MPs, or regional landscape plans). On the contrary, official regional acts only record a very limited number of cases where CMs were integrated within sectoral or territorial plans other than MPs, but even in such cases, integration only concerns planning tools specifically aimed at preserving biodiversity, such as plans for natural protected areas (i.e., national parks or nature reserves) or MPAs' regulatory tools. Indeed, this is consistent with Bouwma et al. [54,55], who have found that existing instruments are seldom used to implement EU policies, while new ad-hoc tools (such as, in this case, CMs or MPs) are usually developed, notwithstanding the absence of any explicit requirement to do so from the directive. This extremely low level of integration calls into question the extent to which nature and biodiversity are integrated within territorial plans, which in turns points to the extent to which human beings perceive the importance of biodiversity, which is irreplaceable in sustaining the natural processes needed to support human life and development. Such general low awareness is also at the root of perceived conflicts between biodiversity conservation and economic development. Hence, research that looks into nature's contributions to people, with particular reference to protected areas (e.g., [56-58]), on the inclusion of ecosystem services' tradeoffs and their assessment within planning processes [59-62], and on the ecosystem approach to spatial planning [63] could, in principle, contribute to raising awareness on the multiple benefits that nature and biodiversity provide to human beings, and at the same time provide new tools to manage the perceived conflicts.

Second, as regards the governance of the SAC designation processes, the European Commission's and member states' competences are clearly defined in the Habitats Directive. However, this study has highlighted that in Italy some biodiversity conservation imperatives that are key to achieving and efficiently managing the Natura 2000 network, such as species monitoring programs, conservation measures definition, and management plan preparation and implementation, have been transferred from the central state to the regions and autonomous provinces. Such transfer of competencies, which has now been in place for over two decades, has left plenty of room for different interpretations among regions. This is clearly shown, for instance, by the fact that some regions have identified CMs and prepared MPs themselves, while others have delegated this task to lower tiers of government, which are probably regarded as closer to local communities and therefore as a better choice to understand social and economic needs and expectations and account for them within CMs and MPs. In this regard, as direction for future research, this study points to the need to better understand whether there is any correlation between the tier of government at which CMs are identified (or MPs are prepared) and their effectiveness in contributing to maintaining habitats and species at a favorable conservation status and ultimately at halting biodiversity loss. To answer this question, further research that looks at whether the choice of institutional level impacts, on the one hand, on biodiversity health and, on the other hand, on the socio-economic conditions of the territories in which Natura 2000 sites have been established, would be needed.

Third, this study has shown that participation in the SAC designation process significantly varies among regions, as regards the form (e.g., written comments versus participation in meetings), the timing (e.g., within the CM or MP preparation, or at the very end), and the consulted actors (e.g., institutions, key stakeholders, local communities). It is worth remarking that, in this article, only the documented implementation of the participatory processes was analyzed. Two recent works [21,22] have proposed an assessment of the participatory processes carried out in some Italian regions; by surveying a small group of stakeholders, the authors have examined issues of inclusiveness, democracy, and conflicts concerning Natura 2000 management and planning, and have argued that only selected stakeholder groups were involved and that information, rather than participation, often took place, seldom allowing for effective integration of local knowledge within MPs. Hence, the authors have 
examined (not randomly or systematically, but through a snowball sampling technique) stakeholders' perceptions concerning their participation in the making of MPs, while this work has proposed a systematic assessment of official documents that have recorded such participation. Therefore, further research could bridge the two assessments and combine a systematic survey of stakeholders who took part (in whichever form) in SAC designation processes with the documental analysis here presented, so as to compare stakeholders' perceptions (on which focus, for instance, [31] and [64]), with the official narrative, hence ultimately assessing participation effectiveness.

Finally, implications on spatial planning only emerge in a limited number of cases and with contrasting perspectives. In the autonomous province of Bolzano, $\mathrm{CMs}$ are subject to the local planning law, similarly to what happens in Friuli Venezia Giulia, where, in compliance with the regional law no. $7 / 2008$, the official acts approving CMs state that, in cases of differences or contradictions, CMs prevail over land use plans and regulations; moreover, the law also mandates that MPs are to be regarded as environmental territorial plans and that municipal land-use plans have to comply with MPs; this latter provision is also stated with reference to MPs approved by the Molise region. In the Apulian case, all of the acts whereby MPs are approved explicitly state that MPs constitute a sectoral planning tool, whose provisions integrate or replace those of the statutory and legally-binding land-use plans in force in the municipality whose territory overlaps the Natura 2000 site of concern; some acts also add that municipal land-use plans need to be revised in compliance with MPs. Moreover, for one Apulian site, the relevant act provides evidence that a Strategic Environmental Assessment procedure was carried out. In such cases, CMs (and MPs as well) are indeed regarded as territorial planning tools. Conversely, Basilicata Region's official acts, on the one hand, declare that CMs must be integrated within land use plans and sectoral plans; on the other hand, they state that MPs are not territorial plans and therefore they are not subject to the Strategic Environmental Assessment procedure. Similarly, MPs are not subject to the Strategic Environmental Assessment procedure also in the Marche region, but on different grounds: In this case, this procedure was regarded as not needed in the absence of actions for which an Environmental Impact Assessment procedure (first introduced in the EU by Council Directive 85/337/EEC) would have been mandatory, and in the absence of any significant adverse impact of the plan's action on the environment. On the contrary, a Strategic Environmental Assessment (also providing a legal framework for stakeholders' inclusion) was considered necessary in Sardinia, because most MPs also comprise interventions aimed at enhancing local assets and resources, or at supporting sustainable local economies, rather than at preserving biodiversity. Such differences concerning the very essence of CMs and MPs (as well as their binding or non-binding character) signal that an in-depth analysis of administrative and urban planning laws is required, possibly leading to a unified (national) legal framework across Italian regions. This would also reinforce the straightforward, yet very important, role played by Natura 2000 sites in spatial planning since the early 1990's, as such areas have contributed, through the Appropriate Assessment Procedure [65], to halting, preventing, or hindering urban and infrastructure development, which has ultimately resulted in supporting biodiversity conservation.

\section{Conclusions}

This study has examined the processes leading to SAC designation in Italy through a systematic qualitative documental analysis of official acts, issues of multi-level governance, inclusion, and the nature and role of CMs and MPs, including their relationship with the wider planning system.

Significant regional differences in the processes through which CMs and MPs have been defined and approved have emerged, which might be an Italian peculiarity because key functions and competences concerning the implementation of the Habitats Directive in Italy have been delegated from the state to regions and autonomous provinces. However, since general delays in establishing and managing SACs have been reported in the literature, the fragmented variety of Italian experiences (for instance, concerning participatory processes or the relationship between CMs and statutory 
planning and, ultimately, the perception and understanding concerning the very essence of CMs) in this regard could parallel that of a number of other EU countries.

Compared to other studies that have examined the implementation of the Habitats Directive, conflicts and participation in site designation, planning, and management, this study has taken a novel approach in that it has investigated the official institutional narrative through a thorough document analysis. Such narrative is usually neglected, and yet it should necessarily complement that of the involved communities and stakeholders, because Natura 2000 is an institutional, top-driven spatial policy that is grounded on a solid, multi-level legal framework comprising (at the very minimum, depending on each member state) directives and national laws. By doing so, this study also contributes to shedding some light on the establishment of conservation measures (eventually included within management plans), which is, so far, still an under-researched topic in the scientific literature, possibly due to the low involvement of the academic world in a process led by public institutions (at the national, regional, or local level, depending on the member state) and typically involving practitioners in natural sciences, forestry, and the marine environment, as far as the identification of measures is concerned.

According to Ferranti et al. [66], biodiversity conservation in the EU has historically been approached in various ways, consisting of a circular path; from an initial technocratic, science-driven, top-down approach (quite apparent in scientific grounded site designations) to a limited inclusion of selected local stakeholders such as farmers or hunters in site management, to the wider inclusion of other economic stakeholders less connected to the sites and yet still affected by site management and restrictions (for instance, tourism businesses), back to technocracy in the current phase, quite informed by the latest environmental economics research on natural capital and ecosystem services, which, according to the authors, results in a renewed marginalization of local communities. The fragmented and varied Italian experience concerning SAC designation suggests that, rather than a sequence of historical phases, the coexistence of various approaches, some more technocratic and some more democratic and inclusive, can be observed depending on the region.

Funding: This research received no external funding.

Conflicts of Interest: The author declares no conflict of interest.

\section{References}

1. European Commission. Communication from the Commission to the Council and the European Parliament on a European Community Biodiversity Strategy. COM (1998)42 final, 1998. Available online: https://eur-lex. europa.eu/legal-content/en/TXT/PDF/?uri=\%20CELEX:51998DC0042 (accessed on 31 December 2019).

2. European Commission. Communication from the Commission to the European Parliament, the Council, the Economic and Social Committee and the Committee of the Regions Our Life Insurance, Our Natural Capital: An EU Biodiversity Strategy. COM (2011)0244, 2011. Available online: https://eur-lex.europa.eu/ legal-content/en/TXT/PDF/?uri=CELEX:52011DC0244 (accessed on 31 December 2019).

3. European Environmental Agency. Natura 2000 Barometer, 2018. Available online: https://www.eea.europa. eu/data-and-maps/dashboards/natura-2000-barometer (accessed on 31 December 2019).

4. Ostrom, E. Governing the Commons: In The Evolution of Institutions for Collective Action; Cambridge University Press: Cambridge, UK, 1990.

5. Lockwood, M. Global protected area framework. In Managing Protected Areas: A Global Guide; Lockwood, M., Graeme, V., Kothari, A., Eds.; Cromwell Press: Trowbridge, UK, 2006.

6. Kukkala, A.S.; Arponen, A.; Maiorano, L.; Moilanen, A.; Thuiller, W.; Toivonen, T.; Zupan, L.; Brotons, L.; Cabeza, M. Matches and mismatches between national and EU-wide priorities: Examining the Natura 2000 network in vertebrate species conservation. Biol. Conserv. 2016, 198, 193-201. [CrossRef]

7. Popescu, V.D.; Rozylowicz, L.; Niculae, I.M.; Cucu, A.L.; Hartel, T. Species, habitats, society: An evaluation of research supporting EU's Natura 2000 network. PLoS ONE 2014, 9, e113648. [CrossRef] [PubMed]

8. Campagnaro, T.; Sitzia, T.; Bridgewater, P.; Evans, D.; Ellis, E.C. Half Earth or whole Earth: What can Natura 2000 teach us. BioScience 2019, 69, 117-124. [CrossRef] 
9. Rauschmayer, F.; Berghöfer, A.; Omann, I.; Zikos, D. Examining processes or/and outcomes? Evaluation concepts in European governance of natural resources. Environ. Policy Gov. 2009, 19, 159-173. [CrossRef]

10. Maiorano, L.; Falcucci, A.; Garton, E.O.; Boitani, L. Contribution of the Natura 2000 Network to biodiversity conservation in Italy. Conserv. Biol. 2007, 21, 1433-1444. [CrossRef]

11. Mckenna, D.; Naumann, S.; Mcfarland, K.; Graf, A.; Evans, D. Literature Review. The Ecological Effectiveness of the Natura 2000 Network. Technical Paper n. 5/2014, 2014. Available online: https://bd.eionet.europa.eu/Reports/ ETCBDTechnicalWorkingpapers/PDF/Ecologic_Effectiveness_of_Natura2000_LitReview_Report.pdf (accessed on 31 December 2019).

12. Trochet, A.; Schmeller, D. Effectiveness of the Natura 2000 network to cover threatened species. Nat. Conserv. 2013, 4, 35-53. [CrossRef]

13. D'Amen, M.; Bombi, P.; Campanaro, A.; Zapponi, L.; Bologna, M.A.; Mason, F. Protected areas and insect conservation: Questioning the effectiveness of Natura 2000 network for saproxylic beetles in Italy. Anim. Conserv. 2013, 16, 370-378. [CrossRef]

14. Zehetmair, T.; Müller, J.; Runkel, V.; Stahlschmidt, P.; Winter, S.; Zharov, A.; Gruppe, A. Poor effectiveness of Natura 2000 beech forests in protecting forest-dwelling bats. J. Nat. Conserv. 2015, 23, 53-60. [CrossRef]

15. Votsi, N.E.P.; Zomeni, M.S.; Pantis, J.D. Evaluating the effectiveness of Natura 2000 network for wolf conservation: A case-study in Greece. Environ. Manag. 2016, 57, 257-270. [CrossRef]

16. Alphandéry, P.; Fortier, A. Can a territorial policy be based on science alone? The system for creating the Natura 2000 network in France. Sociol. Rural. 2001, 41, 311-328. [CrossRef]

17. Haumont, F. Il recepimento della Direttiva negli Stati membri dell'Unione europea The Directive's transposition across the European Union's Member state. In La Conservazione della Natura in Europa. La Direttiva Habitat ed il Processo di Costruzione della Rete Natura 2000 Nature Conservation in Europe. The Habitats Directive and the Making of the Natura 2000 Network; Amirante, D., Ed.; FrancoAngeli: Milan, Italy, 2003.

18. Enengel, B.; Penker, M.; Muhar, A. Landscape co-management in Austria: The stakeholder's perspective on efforts, benefits and risks. J. Rural. Stud. 2014, 34, 223-234. [CrossRef]

19. Beunen, R.; van Assche, K.; Duineveld, M. Performing failure in conservation policy: The implementation of European Union directives in the Netherlands. Land Use Policy 2013, 31, 280-288. [CrossRef]

20. Cent, J.; Grodzińska-Jurczak, M.; Pietrzyk-Kaszyńska, A. Emerging multilevel environmental governance. A case of public participation in Poland. J. Nat. Conserv. 2014, 22, 93-102. [CrossRef]

21. De Meo, I.; Brescancin, F.; Graziani, A.; Paletto, A. Management of Natura 2000 sites in Italy: An exploratory study on stakeholders' opinions. J. For. Sci. 2016, 62, 511-520. [CrossRef]

22. Paletto, A.; Graziani, A.; Brescancin, F.; De Meo, I. Pubblica partecipazione nell'implementazione della rete Natura 2000 in Italia: Le esperienze dei portatori d'interessi Public participation in implementing Natura 2000 network in Italy: Stakeholders' experiences. Forest 2017, 14, 13-27. [CrossRef]

23. Bryan, S. Contested boundaries, contested places: The Natura 2000 network in Ireland. J. Rural. Stud. 2012, 28, 80-94. [CrossRef]

24. Gallo, M.; Malovrh, S.P.; Laktić, T.; De Meo, I.; Paletto, A. Collaboration and conflicts between stakeholders in drafting the Natura 2000 Management Programme (2015-2020) in Slovenia. J. Nat. Conserv. 2018, 42, 36-44. [CrossRef]

25. Bouwma, I.; Beunen, R.; Liefferink, D. Natura 2000 management plans in France and the Netherlands: Carrots, sticks, sermons and different problems. J. Nat. Conserv. 2018, 46, 56-65. [CrossRef]

26. Krott, M.; Julien, B.; Lammertz, M.; Barbier, J.M.; Jen, S.; Ballesteroz, M.; De Bovis, C. Voicing interests and concerns: Natura 2000: An ecological network in conflict with people. For. Policy Econ. 2000, 1, 357-366.

27. Kamphorst, D.A.; Bouwma, I.M.; Selnes, T.A. Societal engagement in Natura 2000 sites. A comparative analysis of the policies in three areas in England, Denmark and Germany. Land Use Policy 2017, 61, 379-388. [CrossRef]

28. Paavola, J. Protected areas governance and justice: Theory and the European Union's Habitats Directive. Environ. Sci. 2004, 1, 59-77. [CrossRef]

29. Rauschmayer, F.; Van Den Hove, S.; Koetz, T. Participation in EU biodiversity governance: How far beyond rhetoric? Environ. Plan. C 2009, 27, 42-58. [CrossRef]

30. Young, J.C.; Jordan, A.; Searle, K.R.; Butler, A.; Chapman, D.S.; Simmons, P.; Watt, A.D. Does stakeholder involvement really benefit biodiversity conservation? Biol. Conserv. 2013, 158, 359-370. [CrossRef] 
31. Laktić, T.; Malovrh, S.P. Stakeholder participation in Natura 2000 management program: Case study of Slovenia. Forests 2018, 9, 599. [CrossRef]

32. Gibbs, D.; While, A.; Jonas, A.E.G. Governing nature conservation: The European Union Habitats Directive and conflict around estuary management. Environ. Plan. A 2007, 39, 339-358. [CrossRef]

33. Kati, V.; Hovardas, T.; Dieterich, M.; Ibisch, P.L.; Mihok, B.; Selva, N. The challenge of implementing the European network of protected areas Natura 2000. Conserv. Biol. 2015, 29, 260-270. [CrossRef]

34. Beunen, R.; de Vries, J.R. The governance of Natura 2000 sites: The importance of initial choices in the organisation of planning processes. J. Environ. Plan. Man. 2011, 54, 1041-1059. [CrossRef]

35. Langhout, W.; Brunner, A.L. The best idea Europe has ever had? Natura 2000: The largest network of protected areas in the world. Georg. Wright Forum 2017, 34, 86-95.

36. Schirpke, U.; Marino, D.; Marucci, A.; Palmieri, M. Positive effects of payments for ecosystem services on biodiversity and socio-economic development: Examples from Natura 2000 sites in Italy. Ecosys. Serv. 2018, 34, 96-105. [CrossRef]

37. Gil, A.; Calado, H.; Costa, L.T.; Bentz, J.; Fonseca, C.; Lobo, A.; Vergilio, M.; Benedicto, J. A methodological proposal for the development of Natura 2000 sites Management Plans. J. Coastal. Res. 2011, 64, 1326-1330.

38. Kovács, E.; Kelemen, E.; Kiss, G.; Kalóczkai, Á.; Fabók, V.; Mihók, B.; Megyesi, B.; Pataki, G.; Bodorkós, B.; Balázs, B.; et al. Evaluation of participatory planning: Lessons from Hungarian Natura 2000 management planning processes. J. Environ. Manag. 2017, 204, 540-550. [CrossRef] [PubMed]

39. Cortina, C.; Boggia, A. Development of policies for Natura 2000 sites: A multi-criteria approach to support decision makers. J. Environ. Manag. 2014, 141, 138-145. [CrossRef] [PubMed]

40. European Commission at Work: Infringement Decisions. Available online: https://ec.europa.eu/atwork/ applying-eu-law/infringements-proceedings/infringement_decisions/index.cfm?lang_code=EN (accessed on 31 December 2019).

41. Postiglione, A. Impact of Natura 2000 Sites on Environmental Licensing. Italian Report, 2006. Available online: https://www.eufje.org/images/docConf/hel2006/IT\%20hel2006.pdf (accessed on 31 December 2019).

42. Amirante, D. La Direttiva Habitat e la rete Natura 2000: Verso un modello europeo di conservazione integrata The Habitats directive and the Natura 2000 network: Towards a European model of integrated conservation. In La Conservazione della Natura in Europa. La Direttiva Habitat ed il Processo di Costruzione della Rete Natura 2000 Nature Conservation in Europe. The Habitats Directive and the Making of the Natura 2000 Network; Amirante, D., Ed.; FrancoAngeli: Milan, Italy, 2003.

43. Castorina, M.; Martimucci, D. Progetto BIOITALY (Biotopes inventory of Italy): Verso la Carta della Natura per la gestione del patrimonio naturale in Italia BIOITALY (Biotopes inventory of Italy) Project: Towards a Nature map to support natural heritage management in Italy. Mondogis 2000, 2, 45-48.

44. Blasi, C. BIOITALY: Natura 2000 in Italy. Ann. Bot. 1996, 54, 31-38.

45. Neven, M.G.G.; Kistenkas, F.H.; Van Apeldoorn, R.C.; Schröder, R.R.G.; Bruszick, A. Eurosites Insights. Image, Implementation, Interpretation and Integration of Natura 2000 in European Perspective (Alterra-rapport 1221-2), 2005. Available online: https://library.wur.nl/WebQuery/wurpubs/fulltext/39692 (accessed on 31 December 2019).

46. Denscombe, M. The Good Research Guide for Small-Scale Social Research Projects, 2nd ed.; Open University Press: Philadelphia, PA, USA, 2003.

47. Materiale Designazione ZSC. Available online: Ftp://ftp.minambiente.it/PNM/Natura2000/Materiale\% 20Designazione\%20ZSC/ (accessed on 31 December 2019).

48. Bryman, A. Social Research Methods, 4th ed.; Oxford University Press: New York, NY, USA, 2012.

49. Scott, J. A Matter of Record. Documentary Sources in Social Research; Polity Press and Basil Blackwell: Cambridge, UK, 1990.

50. Beunen, R.; Van Assche, K. Contested delineations: Planning, law, and the governance of protected areas. Environ. Plan. A 2013, 45, 1285-1301. [CrossRef]

51. Bouwma, I.M.; Kamphorst, D.A.; Beunen, R.; van Apeldoorn, R.C. Natura 2000 Benchmark. A comparative analysis of the discussion on Natura 2000 management issues, 2008. Available online: http://edepot.wur.nl/ 3419 (accessed on 31 December 2019).

52. Ferranti, F.; Beunen, R.; Speranza, M. Natura 2000 Network. A comparison of the Italian and Dutch implementation experiences. J. Environ. Pol. Plan. 2010, 12, 293-314. [CrossRef]

53. Evans, D. Building the European Union's Natura 2000 network. Nat. Conserv. 2012, 1, 11-26. [CrossRef] 
54. Bouwma, I.; Liefferink, D.; Van Apeldoorn, R.; Arts, B. Following old paths or shaping new ones in Natura 2000 implementation? Mapping path dependency in instrument choice. J. Environ. Pol. Plan. 2016, 18, $214-233$. [CrossRef]

55. Bouwma, I.; Arts, B.; Liefferink, D. Cause, catalyst or conjunction? The influence of the Habitats Directive on policy instrument choice in Member States. J. Environ. Plan. Man. 2017, 60, 977-996. [CrossRef]

56. Castro, A.J.; Martín-López, B.; López, E.; Plieninger, T.; Alcaraz-Segura, D.; Vaughn, C.C.; Cabello, J. Do protected areas networks ensure the supply of ecosystem services? Spatial patterns of two nature reserve systems in semi-arid Spain. Appl. Geogr. 2015, 60, 1-9. [CrossRef]

57. Maczka, K.; Chmielewski, P.; Jeran, A.; Matczak, P.; van Riper, C.J. The ecosystem services concept as a tool for public participation in management of Poland's Natura 2000 network. Ecosyst. Serv. 2019, 31, 173-183. [CrossRef]

58. Lecina-Diaz, J.; Alvarez, A.; De Cáceres, M.; Herrando, S.; Vayreda, J.; Retana, J. Are protected areas preserving ecosystem services and biodiversity? Insights from Mediterranean forests and shrublands. Landscape Ecol. 2019, 34, 2307-2321. [CrossRef]

59. De Groot, R.S.; Alkemade, R.; Braat, L.; Hein, L.; Willemen, L. Challenges in integrating the concept of ecosystem services and values in landscape planning, management and decision making. Ecol. Complex. 2010, 7, 260-272. [CrossRef]

60. Geneletti, D. Assessing the impact of alternative land-use zoning policies on future ecosystem services. Environ. Impact. Asses. 2013, 40, 25-35. [CrossRef]

61. Gómez-Baggethun, E.; Barton, D.N. Classifying and valuing ecosystem services for urban planning. Ecol. Econ. 2013, 86, 235-245. [CrossRef]

62. García-Llorente, M.; Harrison, P.A.; Berry, P.; Palomo, I.; Gómez-Baggethun, E.; Iniesta-Arandia, I.; Montes, C.; García del Amo, D.; Martín-López, B. What can conservation strategies learn from the ecosystem services approach? Insights from ecosystem assessments in two Spanish protected areas. Biodivers. Conserv. 2018, 27, 1575-1597. [CrossRef]

63. Yigitcanlar, T.; Teriman, S. Rethinking sustainable urban development: Towards an integrated planning and development process. Int. J. Environ. Sci. Technol. 2014, 12, 341-352. [CrossRef]

64. Blondet, M.; de Koning, J.; Borrass, L.; Ferranti, F.; Geitzenauer, M.; Weiss, G.; Turnhout, E.; Winkel, G. Participation in the implementation of Natura 2000: A comparative study of six EU member states. Land Use Policy 2017, 66, 346-355. [CrossRef]

65. Zoppi, C.; Lai, S. An ontology of the appropriate assessment of Municipal master plans related to Sardinia (Italy). Future Internet 2014, 6, 223. [CrossRef]

66. Ferranti, F.; Turnhout, E.; Beunen, R.; Behagel, J.H. Shifting nature conservation approaches in Natura 2000 and the implications for the roles of stakeholders. J. Environ. Pol. Plan. 2014, 57, 1642-1657. [CrossRef] 